\title{
The Impact of the Effectiveness of a Buzz Marketing Campaign on the Image, Awareness and Purchasing Decision: The Moderating Role of Involvement
}

\author{
Chebli Leila and Gharbi Abderrazak \\ Faculté des Sciences Economiques et de Gestion de Tunis, Tunisie
}

Received 27 September 2012; Accepted 10 October 2012; Published 20 January 2013

\begin{abstract}
This research will be devoted to the study of buzz marketing, a concept that is in expansion in the present advertising landscape, to study its relevance and importance in corporate advertising communication. The object of this communication is to contribute to the comprehension of the effectiveness of a buzz marketing campaign, to determine its contribution to advertising and to analyze the relationship between the brand and the consumer. We also propose an abstract model to establish an explicit and a direct connection between buzz marketing and the variables that measure its effectiveness. We examine the moderating role of involvement on these variables. The review of the literature of this present research demonstrates that the effectiveness of buzz marketing will be analyzed through the main objects pursued by companies usually namely: image to the brand, awareness to the brand and purchasing decision.
\end{abstract}

Keywords: Buzz marketing, image, awareness, purchasing decision, involvement.

\section{Introduction}

In recent years, the concept of marketing has changed dramatically due to complexity of the behavior of individual consumers. Kapferer (1994) reported that in a postmodern society, where mass advertising is increasingly criticized and where individuals show less interest in traditional advertising, marketing has developed alternatives to better communicate with its communication target and target consumer. Diversification behavior has naturally forced the marketing and his men to diversify their approaches, and therefore had to develop techniques to most major behavioral tendencies.
Seeking ingenuity in the advertising and proximity to the customer, advertisers rely more and more buzz marketing. Hetzel (2002) adds that he had to sell his brand to find another way to communicate, it must innovate. Heilbrunn and al (2005) supported that buzz marketing is a term considered by some as vague and imprecise, but this approach is increasingly sought after as companies and counseling agencies are faced with a major communication problem, the one of saturation of consumers against advertising broadcast. We try, in this research, to better understand this term and the aim of this work is to provide clear answers to creative and business are skeptical about this concept in order to guide their choice in their communication strategy.

Copyright (C) 2013 Chebli Leila and Gharbi Abderrazak. This is an open access article distributed under the Creative Commons Attribution License unported 3.0, which permits unrestricted use, distribution, and reproduction in any medium, provided that original work is properly cited. Contact author: Chebli Leila E-mail: leila.chebli@yahoo.fr 
In this context, it is to understand the role of communication in buzz marketing advertising business and highlight the relationship between the buzz marketing and the variables that determine its effectiveness. Our goal is to work then measure the influence of a buzz marketing campaign on the image, awareness and purchasing decision. This research proposes to study: How buzz marketing can it is a mode of communication relevant to a successful advertising campaign targeted? What is the impact and influence of buzz marketing variables that measure its effectiveness?

The answer to these questions is a priority for any company looking for including buzz marketing in its communication policy and to understand the mechanisms of the buzz marketing and their influence on the image, awareness and purchasing decision variables measuring the effectiveness of a buzz marketing campaign. In this way, our research in the context of major concern for businesses seeking to understand the consumer behavior of this communication technique. The challenge of this study is to highlight point by point the benefits of buzz marketing to understand the concept of communication, to explain and to identify areas of work which can be exploited by the creative and professionals in the world of marketing. It is encouraging advertisers to adopt this mode of communication, to convince the specificity of buzz marketing, show interest and try to analyze its relevance.

\section{Theoretical Framework: Conceptual Model and Research Hypotheses}

The conceptual framework of this work is primarily based on the definition of the concept of buzz marketing and its integration into the communication strategy of the company, as well as the analysis and study of the relationship between buzz marketing and variables that measure its effectiveness. We present successively thereafter variables in our conceptual model and research hypotheses. We postulate that the effectiveness of a buzz marketing campaign will be measured through the image, awareness and purchasing decision. What we want is to know what action, buzz marketing influences the variables studied, explains and analyze the relevance of a buzz marketing operation. We measure the direct relationship between marketing and buzz these variables. It is expected that the buzz marketing positively influence these three variables.

\section{The Origins of Buzz Marketing}

In a world where advertising is classic denigrated by a growing consumer, buzz marketing appears to be a real alternative to war trusts. According to the book of Briones and Stambouli (2002), it is mentioned that buzz marketing is initially appeared on the Internet and has an exponential diffusion of the medium. The Internet has been instrumental in the rise of the concept. Indeed, the tools inherent in this type of media used to convey information in a few clicks. The message can be sent directly to a third person.

Born around 1997, it travels out of bounds and win virtual "reality." The best illustration of this phenomenon is the rise of communication campaigns that grow out of the media.

\section{Definition of Buzz Marketing}

Buzz marketing is the implementation of a planned action to advance the cause of mouth. We retain the definition of Morrisey (2007): "The buzz marketing is like a virus, it is ideally spread with a predefined target which will relay the message to the people who love surrounding the same products and services that carry the message." Gicquel (2006), defines the buzz marketing as a technique formerly called "street marketing", it aims to promote products and services in public places in order to develop a "word of mouth" with a large population focused.

According to Billon and Tardieu (2002), buzz marketing is based on word of mouth creating a buzz around a product, service or event. It allows rapid diffusion and mass information that will subsequently relayed by consumers. Buzz marketing is 
considered as a vector of initial communication, interactive, attracting the attention of the target and fully involving potential consumers becoming actors themselves of the brand.

We distinguish the buzz online marketing which is also known as "viral marketing" which, thanks to the development of the Internet within social networks to generate word of mouth and powerful electronic and Internet users become vectors of the trademark or service. Preece (2002), mentioned has two main advantages for brands and companies that implement's.

- It can generate a large number of contacts on the first day of implementation of the buzz.

- Contacts are easy because they are given without hesitation by the individual who becomes an actor buzz and decides in his soul and conscience of the transmission of this message to recipients who have substantially the same interests as him.

The buzz on the Internet only works if it is possible to create a message that the user wants to go. The user must be in the "followed by the message" a special interest or personal satisfaction.

\section{Research Hypotheses}

\section{A. Relationship between Buzz Marketing and Image to the Brand}

In a research study by Walter (2006), argues that the target individual himself chooses it's brands and the messages that they want to promote or propagate and therefore not registered. Makes use of means which facilitate the spread of their message. In response, according to a study by Creamer (2007), individuals or they adopted the message or they reject it, which will be decisive for the future of the product.

The goal is to assign individuals to a message they convey, engendering the assessment of the mark. So here we see the importance of cultivating a good brand image and maximum use of the vector of buzz marketing, to influence the behavior of the target. In their book Kirby and Marsden (2005), it appears that the secret strength is that it can, if its actions are relevant to generate positive word of mouth through vector human communication medium most effective in terms of persuasion. But action buzz marketing can harm the brand by Hughes (2005), that is to say, if it generates a negative and uncontrollable buzz due to the non-appreciation of the brand or the message it tries broadcast.

If good buzz marketing is a great way to promote bad buzz marketing can have dramatic repercussions on brand sales. It is therefore important to ensure that the message wills not hit the susceptibility of potential consumers said Godin (2001) and that the message can't be deformed and be a negative viral marketing. Defy and create emotion, this is what it takes to create a "good buzz" confirms Rosen (2005).

These reasons allow the formulation of our first hypothesis:

\section{H1: "The Buzz Marketing Has a Positive Effect on the Image to a Brand."}

\section{B. Relationship between Buzz Marketing and Awareness to the Brand}

According to an analysis by the authors Muniz and O'guinn (2001), who consider that: buzz marketing can be quickly understood consumers and their sympathy. This is one of the best ways to approach them directly and engaging individuals and thus establishes a relationship with them. Buzz marketing is a key lever diffusion is a communication tool used to advertise a product or brand, develop a buzz marketing seems appropriate as likely to reach the target. According to Kaser (2007), to remain effective buzz marketing should be permanently creativity, mixing fantasy and reality. The ultimate goal is to surprise, aroused the curiosity of consumers and especially to talk about the brand beyond the action. 
The brand tries to make an experience to the consumer by offering to become his privileged ambassador in order to promote a product or service.

These individuals will talk about this meeting around them. This is an interesting use when it comes to generating traffic around a product you want to promote said Rosen (2005). This technique tends to surprise the consumer and especially to talk about the brand beyond the action. As part of a product launch or brand these campaigns are effective and bring positive results when done well. Indeed, Friedman (2007), states that the buzz marketing can be quickly understand consumers and their sympathy.

Furthermore, in holding the theory that considers the buzz marketing is a tool interesting and effective communication within large national or multinational brands and trademarks are beginning to use it extensively.

Following these findings, we propose our second hypothesis:

\section{H2: "The Buzz Marketing Has a Positive} Impact on the Awareness to the Brand"

\section{The Relationship between Buzz Marketing and Purchasing Decision}

According to Cova (2001), who explains that buzz marketing uses social ties of some consumer groups called community (individuals with common behaviors) to promote an offer. This method can offer tailored to different needs of consumers. In the field of the community, the product is a recognition factor, a real tool that creates a link among individuals in the community. In fact, the marketing approach is specific. According Riou (2003), the product must not only respond to a need, but also be a vehicle built on the values of the group. The product should ideally be an object, a symbol of recognition among members of the community. According to Hetzel (2003), communication about the offer will be the lever to its acceptance by the community. The means of communication used to promote a product must meet the criteria of belonging to a community as it is. The image of the offer must be monitored very carefully.

Manafy (2007) supports this concept that the individual holds the central place. It is no longer just a consumer becomes an actor but his own consumption and influence the consumption of others. Through the message it conveys, "consumer-actor" asserts itself through certain values. It will therefore select brands in functions of the values attached to it and will do the same for messages.

In light of the foregoing, our third hypothesis is proposed:

\section{H3: "The Buzz Marketing Positively Influences Brand Choice When Making Purchasing Decision."}

D. The Moderating Role of Consumer Involvement: The Relationship between Buzz Marketing, Involvement and Image to the Brand

According Chetochine (2006), his analysis is based on the fact that: consumers become "consommacteur" means an experience by becoming an active brand vector. Buzz marketing is a response to this desire. The consumer is involved in the life of the brand and saw a story through its consumer brands and therefore it consumes. Brands want to build relationships with consumers by surprise in their own environment. Buzz marketing is therefore to recover the link between the brand and the consumer environment. This new consumer involvement will help generate word of mouth that meets the objectives of the company and thus affect many people.

In the book Matathia and al (2004), stresses that companies should be able to use the advantages offered by the buzz marketing. The receiver must keep in his mind a sense of freedom for the operation to be well received. It should not feel manipulated. Should be offered, rather than imposing. 
Buzz marketing meets consumer expectations because it involves the communication of brands and thus mentioned Fahy (1998), so they can create a relationship of interaction between the consumer and the brand. Buzz marketing can meet a genuine willingness of consumers to be considered full participants of the brand and not just as consumers. Thus, the post-modern consumer is primarily a consommacteur. According to Godin (2005), being too wanted to involve the consumer can have the opposite effect to that intended. So instead of coming to him, it is preferable that it is he who makes the first move. He must have wanted himself to be involved, to interact with its environment. It is the same for creating a link between the brand and the target: it must be made freely and without the receiver perceives the shadow of the mark that hangs over this interaction. The secret is: to inspire moderation in consumer involvement mention Moors (2003). Involvement influences both directly to the brand image and interacts with the buzz marketing.

Thus, we propose to formulate our fourth hypothesis:

H4: "The Involvement Moderates the Relationship Between Buzz Marketing and Image to the Brand."

H4.A: "More people are involved in the operation of buzz marketing, the image is positive towards the brand."

H4.B: "More people are involved in the operation of buzz marketing, the relationship between the buzz marketing and image to the brand is strong."

\section{Model Search}

The literature review presented allows proposing a conceptual model of the variables that may be involved in the direct relationship between the buzz marketing and the determinants of the effectiveness of a buzz marketing campaign. This model summarizes all the assumptions made in the previous paragraphs. The involvement of each of these variables inserted is specified and its introduction into our research is warranted. Our research concerns the impact of the effectiveness of a buzz marketing campaign image, awareness and purchasing decision are our dependent variables. These variables allow us to evaluate the effectiveness of a buzz marketing operation. The independent variable of our model is the buzz marketing. According to previous research, the involvement influences the effectiveness and relevance of buzz marketing least at the image. That is why we have introduced this variable in our conceptual model as a moderating variable.

Relations studied in this research are illustrated in the figure below:

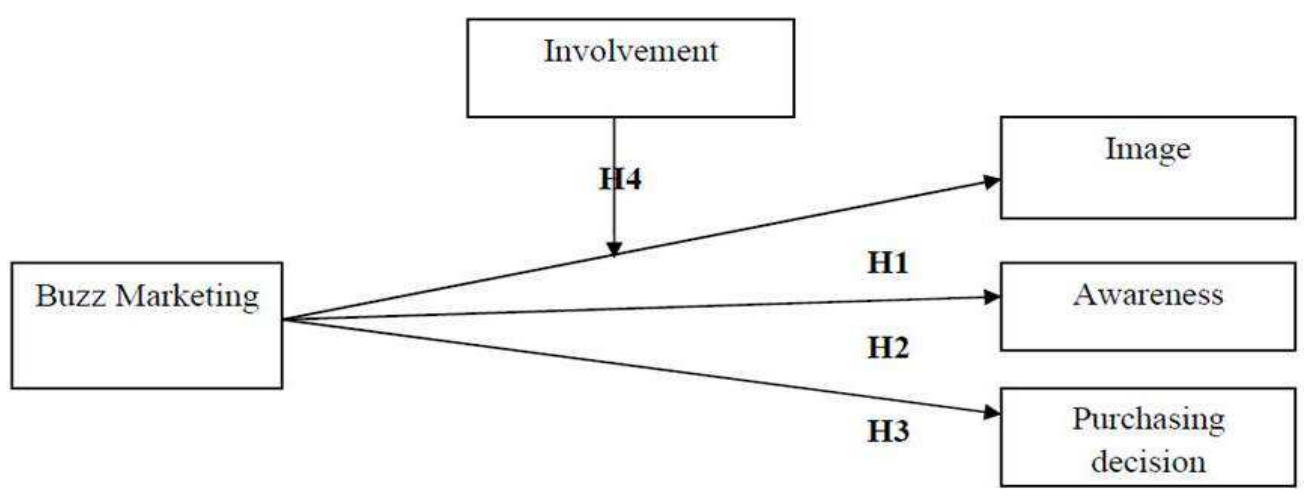

Figure 1. The Impact of the Effectiveness of a Buzz Marketing Campaign on the Image, Awareness and Purchasing Decision: The Moderating Role of Involvement 


\section{Conclusions, Implications and Future Research Way}

The main objective for this study is to propose a structural model to better explain the relationship between buzz marketing and efficacy variables campaign of a buzz marketing namely the image, awareness and purchasing decision, developed in the literature. Trying to integrate the moderator variable involvement in the relationship between buzz marketing and image to the brand, our goal is to enrich the modeling theory of consumer behavior.

According Bardidia and al (2007), Badot and Cova (2003), or Godin (2001), buzz marketing draws heavily among young people [15 years and 30 years] and those aged 50 years and older. In addition, some authors, such as Chetochine (2006), who pointed out that this type of campaign, can be considered independently of the level of study.

Based on these findings, we will try in previous research to test our research model and study the relationships between the different variables of the model. According to a research done by Engel (2006) and Dru (2007), companies are aware of the changing consumer behavior, and use more this technique is growing. Indeed, the characteristics of a buzz marketing operation seem to respond effectively to the specific needs of consumers.

The literature has shown that the consumer must itself take the first step, so that the operation is well received. In a research study by Morrissey (2007), states that the consumer must have a sense of freedom, the desire for involvement and interaction must be for successful buzz marketing campaign. Otherwise would be inconsistent with the principle of buzz marketing. By offering simple actions, attractive, innovative, creative, original, mysterious (the teasing), entertaining and even shocking but not excessive, the consumer adheres to the concept without prejudice mentioned Devin (2006). It has been shown theoretically that buzz marketing campaign influences the variables that measure its effectiveness, including image, awareness and purchasing decision. Indeed, because of its efficiency, buzz marketing offers direct stimuli, sensory renewal, a direct response to a need and possibly the production of meaning leading to an interaction between the consumer and the brand. It is based on a speech exchange. Henceforth, this work will allow us to establish a direct relationship between the buzz marketing and these variables. This research would also allow us to study the impact of a buzz marketing campaign on these variables and to better understand and target consumers to identify their different expectations.

This study opens broad avenues of research. We will remember them:

- Finish this study, an empirical study to verify the validity of the theory in order to be able to apply to other fields marketing.

- Make a qualitative study to attach advantage to know the consumer behavior accurately address this communication technique by collecting their opinions and attitudes about the practice of this kind of concept.

\section{References}

Arnould, E. J. \& Thomson, C. J. (2005). "Consumer Culture Theory (OCT): Twenty Years of Research," Journal of Consumer Research 31, 868-882.

Badot, O. \& Cova, B. (1992). "Des Marketings en Mouvement, Vers Un NéoMarketing?," Revue Française du Marketing (136), 5-27.

Badot, O. \& Cova, B. (1995). "Communauté et Consommation: Prospective Pour Un Marketing Tribal," Revue Française du Marketing (151), 5-17.

Badot, O. \& Cova, B. (2003). "NéoMarketing, 10 ans Après: Pour Une Théorie Critique de La Consommation et du Marketing Réenchanté Néo-Marketing," 
Revue Française du Marketing 195 (5), 7995.

Billon, D. \& Tardieu, J. M. (2002). Les Nouvelles Techniques de Marketing, Chiron.

Carl, W. J. (2006). "What's All the Buzz About? Everyday Communication and the Relational Basis of Word-of-Mouth and Buzz Marketing Practices," Management Communication Quarterly (Mcq), 19 (4), 601-635.

Chetochine, G. (2007). Tu Buzz or Not to Buzz: Comment Lancer Une Campagne de Buzz Marketing, Evrolles.

Christensen, L. T., Torp, S. \& Firat, A. F. (2005). "Integrated Marketing Communication and Postmodernity: An Odd Couple?," Corporate Communications, 10 (2), 156-168.

Coutelle-Brillet, P. (2004). Marketing- de L'analyse a L'action, Pearson Education, France.

Cova, B. (1997). "Community and Consumption Towards a Definition of the "Linking Value" of Product or Services," European Journal of Marketing, 31 (4), 297318.

Cova, B. (2000). 'Au-Delà du Marché: Quand Le Lien Importe Plus Que Le Bien,' L'Harmattan.

Cova, V. \& Cova, B. (2001). 'Alternatives Marketing,' Dunod, Paris.

Creamer, M. (2007). 'What's Plaguing Viral Marketing,' Advertising Age, 78 (28), 1-3.

Damperat, M. (2006). "Vers Un Renforcement de La Proximité des Relations Client," Revue Française de Gestion, 32 (162), 115-127.

Decaudin, J. M. (2003). La Communication Marketing, Concepts, Techniques, Stratégies, Economica.

Decaudin, J. M. \& Digout, G. (2011). EPublicité: Les Fondamentaux, Dunod, Paris.
Desmet, P. (2003). Marketing Direct: Concepts et Méthodes, Dunod, Paris.

Dru, J. M. (2007). La Publicité Autrement, Gallimard, Paris.

Engel, A. L. (2006). 'The Best of the Buzz,' Adweek, 47 (33), 22-23.

Fahy, J. (1998). 'Postmodern Marketing,' Journal of Marketing, 62 (1), 121-124.

Firat, A. F. \& Venkatesh, A. (1993). "Postmodernity: The Age of Marketing," International Journal of Research in Marketing (10), 227-249.

Friedman, S. (2007). 'Viral Marketing,' National Underwriter, 111 (38), 5-6.

Fuat Firat, A., Dholakia, N. \& Venkatesh, A. (1995). "Marketing in a Postmodern World," European Journal of Marketing, 29 (1), 40-57.

Gicquel, Y. (2006). Le Buzz Marketing, Le Génie des Glaciers.

Godin, S. (2001). Les Secrets du Marketing Viral: Le Bouche à Oreille à La Puissance 10, Maxima, Paris.

Godin, S. (2005). Permission Marketing: La Bible de L'internet Marketing, Maxima, Paris.

Hermel, L. P. (2007). 'Le Marketing, Eyrolles,' Economica.

Hetzel, P. (1996). "Les Entreprises Face Aux Nouvelles Formes de Consommation," Revue Française de Gestion, (110), 70-82.

Hetzel, P. (2002). Planète Conso, Marketing Expérientiel et Nouveaux Univers de Consommation, Organisation.

Hetzel, P. (2003). "Pratiques et Tabous du Marketing: Segmenter Par Les Critères Ethniques et Communautaires," Décisions Marketing, 32, 97-105.

Hughes, M. (2005). 'Buzz Marketing,' Portfolio Hardcover. 
Ingold, P. (2007). 'Guide Opérationnel de La Publicité a L'usage des Entreprises,' Dunod, Paris.

Jouve, M. (2002). Communication- Théories et Pratiques, Bréal.

Kapferer, J. N. (1994). 'La Fin D'un Marketing?'' Revue Française de Gestion, (100), 65-70.

Kaser, D. (2007). "The Art of Generating Buzz," Information Today, 24 (7), 9-12.

Kirby, J. \& Marsden, P. (2005). Connected Marketing: The Viral, Buzz and Word of Mouth Revolution, Taylor \& Francis.

Lendrevie, J., Lindon, D. \& Levy, J. (2003). 'Mercator: Théorie et Pratique du Marketing,' Dalloz Gestion, Paris.

Leonard. D. (2006). 'Viral Ads: It's An Epidemic,' Fortune, 154 (7), 61-66.

Manafy, M. (2007). 'Viral Video,' Econtent, 30 (5), 3-4.

Matathia, I., O'reilly, A. \& Salzman, M. (2004). 'Buzz: Le Marketing du Bouche a Oreille,' Village Mondial.

Moors, B. (2003). Les Clés de La Publicité Aujourd'hui, Maxima, Paris.

Morrissey, B. (2007). "Brands Infiltrate Social Circles to Create Buzz," Adweek, 48 (39), 14-15.

Morrissey, B. (2007). 'Clients Try to Manipulate 'Unpredictable' Viral Buzz,' Adweek, 48 (12), 12-13.

Muniz, A. M. \& O'guinn, T. C. (2001). "Brand Community," Journal of Consumer Research 27 (4), 412-433.

Pras, B., Evrard, Y. \& Roux, E. (2003). Market: Etudes et Recherches en Marketing, Dunod, Paris.

Preece, J. (2000). 'Online Communities: Designing Usability, Supporting Sociability,' John Wiley \& Sons.
Remy, E. (2001). "Le Lien Social Dans Le Marketing des Services," Revue Française du Marketing, (181), 97-109.

Riou, N. (2003). "Quand La Publicité Devient Postmoderne," Revue Française du Marketing, 89-96.

Rosen, E. (2005). 'The Anatomy of Buzz: How to Create Word-of-Mouth Marketing,' Currency.

Treguer, J. P. \& Segati, J. M. (2005). Les Nouveaux Marketings: Marketing Générationnel, Gay Marketing et Marketing Ethnique, Dunod, Paris.

Solomon, M. R. (2003). 'Consumer Behavior,' Prentice Hall.

Solomon, M. R., Heilbrunn, B. \& TissierDesbordes, E. (2005). Comportement du Consommateur, Pearson Education, France.

Stambouli, K. (2003). "Marketing Viral et Publicité," Revue Française du Marketing, (193), 97-107.

Stambouli, K. B. \& Briones, E. (2002). Buzz Marketing Les Stratégies du Bouche- AOreille, Organisation.

Steyer, A., Garcia-Bardidia, R. \& Quester, P. (2007). "Modélisation de La Structure Sociale des Groupes de Discussion Sur Internet: Implications Pour Le Contrôle du Marketing Viral," Recherche et Application en Marketing, 22 (3), 29-44. 